\title{
THE FIRST PAGE
}

I don't know whether your grandchildren are as uninformed as mine or not, but $I$ have written this trifle of nugacity because I was shocked to find that mine didn't know what a running board was. They thought it had something to do with water skiing. That started an intensive investigation on my part, and in plumbing their intellectual depth, I discovered they had never even heard of fypaper, stretchberries, sheep sorrel, peppergrass, or a hundred other things. Well, you can't let a thing like that go on.

The activities of big things of the past, like dirigibles or blimps, will be recorded by up-and-doing historians, but I've just worried like anything about who is going to immortalize, in the written word, a whole world of little things that once enriched the young lives of those emerging into the twentieth century.

Loosely speaking, this book is a sort of family story. I have used a few of its members as one uses dummies, upon which to hang clothing. I have not tried to lift the mind into the higher reaches of intelligence. What I'm about is that I don't want anybody to skip lightly over the important years of my generation. The young may hardly realize how many things have gone off completely and how many vital things have come on strong during this period which covers the merging 
of two centuries, leaving us with a residue of remarkable interest and a strange uncertainty as to what still undoubtedly will come.

I have allotted a place to many of the "gone off" and "come on" things: the flypaper and the stretchberries-trivial perhaps, but indicative of the times. To present the record of these years it seemed best to convey it through the eyes, thoughts, and reactions of a youngster actually growing up through this upheaval of changes, together with the inevitable differences of opinions between two generations with such altering, such differing problems.

Basically the story is as truthful as I can make it, but occasionally my mind opens up and because of its light texture it escapes-through a kind of hatch-and is immediately airborne. When it gets too involved with high flying I simply change the subject matter to bring it back to earth. I trust the reader will recognize these shifts in altitude for what they are.

It takes thirty years for a period to acquire the quality of nostalgic charm, but after double that number of years I'm not nostalgic about anything. It does, however, please me to do what I can to line up a sort of random sample of my time on a whole row of pins before the memory of them dies out everywhere.

There are four people who have aided me in many ways. Pauline Naylor who guided me at the beginning when I needed it most. Fred Cotten, historian of Weatherford Texas -a contemporary of mine-has a vast store of knowledge of the area concerned herein, and graciously helped me pin point dates and general information. John Graves, already posessed of literary fame, kindly gave me a carefully balanced amount of helpful criticism coupled with encouragement. And my beloved brother, George Donald Bowie, dug up family lore that he had hoarded away all these years. To these four I gratefully acknowledge my utmost thanks. 